Ivan TOMIĆ, asistent

Pravni fakultet Sveučilišta u Mostaru

ivan.tomic@pf.sum.ba
UDK: 342.924

Pregledni znanstveni rad

Primljen: 21. 3. 2020.

Prihvaćen: 8. 6. 2020.

\title{
TUMAČENJE, PRAVNE PRAZNINE I NAČELO ZAKONITOSTI
}

\begin{abstract}
Sažetak: Učlanku autor analizira odnos između tumačenja, pravnih praznina i načela zakonitosti. Tumačenje je jedna od faza u primjeni pravne norme. Pravne norme propisane su apstraktno za neodređen broj slučajeva. Stoga se pri primjeni pravne norme, kao prethodni zahtjev, javlja zahtjev za tumačenjem. Zadatak je tumača utvrditi moguća značenja pravne norme i primijeniti ono značenje koje najbolje odgovara u konkretnom slučaju. U pravnoj znanosti razvijena su određena pravila, metode tumačenja koje se primjenjuju u postupku tumačenja. Postupak tumačenja najčešće zahtijeva primjenu više metoda kako bi se utvrdilo koje je od mogućih značenja najbolje primijeniti. Međutim, osim potrebe utvrđivanja značenja pravne norme, ponekad se u pravnom sustavu pojavljuju takvi slučajevi koji predstavljaju pravnu prazninu. U tim slučajevima tumač treba tumačenjem dostvoriti postojeću pravnu normu kako bi bila primjenjiva, a da istodobno ne povrijedi načelo zakonitosti. Načelo zakonitosti bilo je predmetom razmatranja i pred Europskim sudom za ljudska prava. Autor u radu predlaže primjenu diskrecijskih ovlasti od suca pod uvjetom da takve diskrecijske odluke ostanu u okvirima načela zakonitosti.
\end{abstract}

Ključne riječi: tumačenje, metode tumačenja, pravna praznina, načelo zakonitosti, Europski sud za ljudska prava.

\section{Uvod}

Pravni poredak sadrži mnoštvo međusobno povezanih pravnih normi. Zadatak je tumača primijeniti mnogobrojne i raznovrsne pravne norme u konkretnom slučaju. Iako se na prvi pogled može činiti da se radi o jednostavnom zadatku, analizom bilo kojeg predmeta dolazi se do drukčijeg zaključka. Da bi se pravna norma primijenila, kao prethodni korak u njezinoj primjeni potrebno je izvršiti tumačenje. Dakako, ponekad će biti lako protumačiti pravnu normu, ali u teškim slučajevima trebat će primijeniti različite metode, argumente i tehnike da bi se utvrdio i odabrao smisao pravne norme koji je najbolje upotrijebiti. 
U različitim etapama razvoja pravne znanosti postojala su različiti stavovi o tumačenju. Pojedine škole ${ }^{1}$ smatrale su da je sudac, odnosno onaj koji primjenjuje pravnu normu, samo vox legis (glas zakona). Danas je gotovo općeprihvaćeno mišljenje da pravnu normu uvijek treba tumačiti prije njezine primjene. ${ }^{2,3}$

U kontekstu primjene pravne norme i tumačenja javlja se pojam pravnih praznina. Tumačenje ne znači samo primjenu postojeće norme nego uvijek i određenu mjeru stvaranja postojeće norme. Mogu li se tumačenjem popuniti pravne praznine ili su one proizvod tumačenja? Ako se tumačenjem stvara novi dio pravne norme koji do tada u pravnom sustavu nije postojao, postavlja se pitanje je li tumačenje odnosno dostvorena pravna norma kao proizvod tumačenje u sukobu s načelom zakonitosti? Na spomenuta pitanja autor će pokušati odgovoriti u nastavku rada.

Rad je tematski podijeljen na uvodna razmatranja u kojima se iznose neka osnovna pitanja; središnje dijelove rada koji analiziraju institute tumačenja, pravnih praznina, načela zakonitosti i njihov međusobni odnos te praksu Europskog suda za ljudska prava u odnosu na stavove tog suda prema načelu zakonitosti, dopustivosti i utjecaju tumačenja na načelo zakonitosti te zaključna razmišljanja.

Takav stav zauzimale su pozitivističke teorije prava. One su iznosile tezu da je sudac živi glas zakona. Tvorac te teze je Montesquie u svom čuvenom djelu 'O duhu zakona". Osnovna maksima pravnog pozitivizma kao ideologije može se ovako iskazati: treba poslušati zakone kao takve, dok je osnovna maksima prirodnopravne teorije: treba poslušati zakone samo ako su pravedni. U prvom slučaju su sami zakoni kriterij pravednog i nepravednog; u drugom slučaju su i zakoni podvrgnuti jednom višem kriteriju vrednovanja (do kojega se dolazi, u naturalističkoj etici, preko spoznaje ljudske prirode). O odnosu prirodnopravne i pozitivističke teorije vidi više: BOBBIO, N., Jusnaturalizam i pravni pozitivizam, Revus, br. 26., Kranj, 2015., str. 19. - 32., dostupno na: https://journals.openedition.org/ revus/3409 (24. 1. 2020.).

2 Karas navodi da je Justinijanova zabrana tumačenja propisa postala poznata po nemogućnosti korištenja, a naivnim je označen i sličan Beccarijin prijedlog da tumačenje ne smije biti prepušteno sucima jer oni nisu zakonodavci i mogli bi uključiti osobna gledišta. Vidi: KARAS, Ž., Neujednačena sudska praksa u kaznenom postupku kao povreda Europske konvencije za zaštitu ljudskih prava, Zbornik Pravnog fakulteta u Zagrebu, vol. 64, br. 1, Zagreb, 2014., str. 111. - 131., dostupno na: https://hrcak.srce.hr/121523 (24. 1. 2020.).

3 Ademović zauzima suprotno stajalište prema kojem nema potrebe za tumačenjem ako je norma jasna i precizna. Vidi: ADEMOVIĆ, N., Značaj i metode tumačenja kroz praksu Ustavnog suda Bosne i Hercegovine, Anali Pravnog fakulteta Univerziteta u Zenici, god. 5, br. 9., Zenica, 2012., str. 29. - 34., dostupno na: http://prf.unze.ba/Docs/Anali/godina_5_broj_9/N_Ademovic.pdf (24. 1. 2020.). 


\section{Tumačenje: pojam, predmet i subjekti}

Tumačenje je nužna etapa u procesu primjene pravne norme budući da je prirodi pravnih normi imanentna stanovita neodređenost. Razlozi neodređenosti ${ }^{4}$ mogu biti subjektivne (brzina u postupku izrade i donošenja zakona, nedovoljno znanje i vještine osoba koje sudjeluju u izradi i donošenju norme) i objektivne prirode (nesavršenost jezika, neodređenost i višeznačnost pojmova, visok stupanj apstrakcije i generalizacije u formuliranju normi). ${ }^{5}$ Gotovo da se ne može reći da u nekom pravnom sustavu postoji pravna norma koja se može primijeniti bez tumačenja. Drugo je pitanje hoće li u konkretnom slučaju biti dostatno jezično tumačenje ${ }^{6}$ ili će se trebati primijeniti i drugi argumenti da bi se protumačila norma.

Guastini navodi da je i sama riječ tumačenje višestruko dvosmislena barem u četiri pogleda:

postupak/proizvod; apstraktno/konkretno; spoznaja/odluka i tumačenje/pravno konstruiranje. $^{7}$

Visković definira tumačenje „kao duhovnu djelatnost koja otkriva moguća značenja pravnih normi i u njima hipoteze, traženja, određenja delikta i sankcije, te odlučuje koje je od tih značenja najbolje. ${ }^{\text {" }}$ Kelsen smatra da je tumačenje "postupak duha koji prati proces stvaranja prava u njegovu napredovanju od višeg stupnja na tim višim određen niži stupanj. ${ }^{\text {"9 }}$ Ovakav stav Kelsena podudaran je $s$ njegovim stavom da je stvaranje prava uvijek i primjena prava i posebnom ulogom suda koju mu Kelsen pridaje. Norma koja regulira stvaranje druge norme je primijenjena $\mathrm{u}$ stvaranju te druge norme. ${ }^{10}$ Vrban navodi da tumačenje $\mathrm{u}$ pravu predstavlja pronalaženje smisla pravnih izraza, iskaza, poruka i tekstova. ${ }^{11}$

4 O subjektivnim i objektivnim razlozima vidi: MUHIĆ, F., Teorija države i prava, Editio Iuristica, Sarajevo,1999., str. 331. - 333.

Tako ANTIĆ, T., Vjerodostojno tumačenje zakona, Zbornik Pravnog fakulteta Sveučilišta u Rijeci, vol. 36, br. 1, Rijeka, 2015., str. 619. - 644., dostupno na: https://hrcak.srce. hr/141269 (25. 1. 2020.).

$6 \quad$ Iako ne postoji suglasje o redoslijedu argumenata, općenito se smatra da se u razumijevanju pravnih normi i odredaba neizbježno mora polaziti od njihove osnovne znakovne građe - jezika. Tako VISKOVIĆ, N., Teorija države i prava, Birotehnika, Zagreb, 2001., str. 248.

Vidi GUASTINI, R., Sintaksa prava, Naklada Breza, Zagreb, 2018., str. 351. - 358. VISKOVIĆ,N., op. cit., str. 243.

$9 \quad$ KELSEN, H., Čista teorija prava, Naklada Breza, Zagreb, 2012., str. 73.

10 KELSEN, H., General theory of law and state, Harward University Press, Cambridge, 1949., str. 133.

11 VRBAN, D., Uvod u državu i pravo, Birotehnika, Zagreb, 1998., str. 80. 
U odnosu na predmet tumačenja postoje različita gledišta. Odnosi li se predmet tumačenja na pravnu normu ili pravnu odredbu? Je li tumačenje usmjereno samo na pravne propise ili su predmet tumačenja i konkretne činjenice? Autor ovog rada smatra da je predmet tumačenja u prvom redu pravna odredba, a potom pravna norma. Naime, kako navodi Visković, jedan je od složenijih i bitnijih poslova pravnika utvrditi cjelovitu pravnu normu. ${ }^{12}$ Prema Viskoviću, pravna norma sastavljena je od hipoteze, traženja, određenja delikta i sankcije. ${ }^{13}$ U velikom broju slučajeva pravna norma sadržana je u više pravnih odredbi. „Postupak kojim se otkrivaju značenja jedne norme tako da se međusobno povezuju i dopunjuju elementi te norme što se nalaze u različitim odredbama "14 naziva se sistematsko tumačenje. Prema tome, onaj tko treba razriješiti konkretni slučaj, u prvom redu treba tumačiti pravnu odredbu (koja može biti ujedno i pravna norma ako sadrži sve elemente pravne norme, odnosno ako je jedna pravna norma izražena u jednoj pravnoj odredbi). Tek ako se tumačenjem pravne odredbe ne može razriješiti konkretan slučaj, tumač će primjenom sistemskog tumačenja utvrditi cjelovitu pravnu normu te potom tumačenjem pravne norme pokušati otkriti njezino značenje. U slučaju da niti sistemskim tumačenjem nije moguće utvrditi značenje pravne norme, valja se primijeniti ciljno tumačenje pravne norme ${ }^{15} \mathrm{U}$ odnosu na konkretne činjenice, autor se može prikloniti Guastiniovu stavu prema kojem se predmet tumačenja in concreto odnosi na pravnu kvalifikaciju nekog činjeničnog stanja, odnosno tumačenjem se treba utvrditi spada li neko konkretno činjenično stanje u područje primjene neke dane, prethodno utvrđene norme da bi se riješio neki spor ili barem kvalificiralo neko konkretno činjenično stanje. ${ }^{16}$ Visković pri određenju predmeta tumačenja izražava kulturalistički stav prema kojem se tumači „svaka pravna radnja (pravni akt), tj. svako pravno relevantno ljudsko ponašanje ukoliko ono predstavlja poruku. "17 Danas se u pravnoj znanosti smatra da glavni predmet tumačenja mogu biti sve pravne norme, a kao sporedni predmet i ljudske radnje ako su pogodne za tumačenje. ${ }^{18}$

$12 \quad$ VISKOVIĆ, N., op. cit., str. 172.

13 Ibid, str. 157.

Ibid, str. 253.

Autor u tekstu koristi izraz tumačenje pravne norme budući da u spornim slučajevima tumačenje obično ne završava tumačenjem pravne odredbe, nego će biti potrebno protumačiti cjelovitu pravnu normu što je sadržana u različitim pravnim odredbama. GUASTINI, R., op. cit., str. 351. - 352.

HARAŠIĆ, Ž., Viskovićeva teorija tumačenja u pravu, Zbornik radova Pravnog fakulteta u Splitu, vol. 48, br. 1, Split, 2011., str. 57. - 72., dostupno na: https://hrcak.srce.hr/66425 (26. 1. 2020.).

Tako KURTOVIĆ, R., Tumačenje prava - Pravna hermeneutika, Pravne teme, god. 4., br. 7, Novi Pazar, 2013., str. 49. - 62. 
Tumačenje valja razlikovati i prema subjektima koji vrše tumačenje. Kako navodi Miličić, „objašnjenja samo određenih pojedinaca ili/i udruga pojedinaca imaju obvezujuću moć, jednako kao i sama pravna pravila koja su predmetom objašnjenja, dočim su moguća i objašnjenja pravnih pravila od određenih pojedinaca i udruga pojedinaca koja imaju neku - predvidivu, osobitu opću težinu, iako neprijeporno nisu u dogmatsko - pravnom smislu obvezujuća objašnjenja pravnih pravila. " ${ }^{19,20} \mathrm{U}$ literaturi se razlikuju raznovrsne podjele, primjerice stručno i nestručno tumačenje, apstraktno i konkretno tumačenje, autentično i neautentično tumačenje i druge podjele. Autor smatra da je najsvrsishodnija klasifikacija tumačenja na obvezujuće i neobvezujuće tumačenje.

Obvezujuće tumačenje je ono koje vrše subjekti koji obnašaju neki oblik pravne vlasti i kojima je ovlast dodijeljena pravnom normom kojom se regulira nadležnost tih tijela. Takvo tumačenje daju sudovi kad rješavaju pravne sporove; upravna tijela kad odlučuju u upravnom postupku. Posebna vrsta obvezujućeg tumačenja je i autentično tumačenje od tijela koje je donijelo pravni akt koji se tumači. ${ }^{21}$

Neobvezujuće tumačenje je ono tumačenje koje vrše pojedinci kako bi utvrdili pravno dopušteni okvir i uskladili svoje ponašanje s tim okvirom. Posebna vrsta tumačenja koje se može podvesti pod neobvezujuće je tumačenje pravnih znanstvenika ili doktrinarno tumačenje. Antić navodi da su „znanstvena (doktrinarna) tumačenja pravnih normi izuzetno značajna jer svojom stručnošću i uvjerljivošću mogu znatno utjecati na subjekte koji donose i one koji primjenjuju propise. Ta tumačenja, međutim, nemaju obvezujuću snagu ni za koga." ${ }^{22}$

\subsection{Metode tumačenja}

Pojam metoda tumačenja koristi se da bi označio skup pravila koje valja primijeniti pri tumačenju pravnih normi ${ }^{23}$ Budući da tumačenje kao preduvjet

19 MILIČIĆ, V., Opća teorija prava i države, Zagreb, 2003., str. 354.

20 Miličić koristi izraz objašnjenje umjesto tumačenje. On smatra da „naziv tumačenje nije primjeren, jer mu je osnovna upotreba u značenju nekome nešto s nekog stranog jezika razlagati, tumačiti.“ Ibid, str. 352.

ANTIĆ, T., op. cit., str. 622.

Loc. cit.

Kregar navodi Weberovu klasifikaciju razvoja prava u kojem stvaranje i tumačenje prava od pravnih znalaca zauzima drugu etapu razvoja. Fazni razvoj prava teče od karizmatske pravne vlasti kroz pravo proroka, zatim stvaranje i tumačenje prava od strane pravnih znalaca, potom nametanje prava svjetovnih ili teokratskih moćnika te naposljetku sistemska elaboracija prava i profesionalno administriranje pravde od strane osoba koje su proš- 
primjene pravne norme eo ipso podrazumijeva složen kognitivni proces spoznavanja sadržaja pravne norme, koji je često višeznačan i neodređen, u najvećem broju slučajeva bit će potrebno primijeniti više metoda - pravila tumačenja. Pravila tumačenja najčešće se razvrstavaju na sljedeća: jezično tumačenje, logičko tumačenje, sistematsko tumačenje, ciljno tumačenje, subjektivno i objektivno tumačenje, povijesno tumačenje te doslovno, suženo i prošireno tumačenje. ${ }^{24}$

Jezično tumačenje je tumačenje u kojem se smisao neke pravne norme otkriva pomoću jezičnih pravila: leksikologije, sintakse i gramatike. Upotrebom jezičnih pravila može se otkriti koja sva moguća značenja ima pravna norma. Jezično tumačenje otkriva moguća značenja neke norme, ali ne daje odgovor na pitanje koje od tih mogućih značenja treba primijeniti u konkretnom slučaju. Potreba za jezičnim tumačenjem veća je ako se u pravnim normama koriste nestručne riječi, primjerice zloupotreba, savjesnost, uzdržavanje i slično. S druge strane, potreba za jezičnim tumačenjem manja je kad se koriste stručni pravni izrazi, primjerice pravni lijek, tužba, žalba. Osobitom vrstom skupa stručnih riječi mogu se kvalificirati norme definicije. To su one norme koje daje sam tvorac pravnog akta, najčešće na početku pravnog akta. Definiranjem značenja izraza što se koriste $u$ pravnom aktu smanjuje se mogućnost različite interpretacije istih. Tako, primjerice, Kazneni zakon Federacije Bosne i Hercegovine definira da je dijete u smislu zakona osoba koja nije navršila četrnaest godina. ${ }^{25}$ Jasno je da izraz dijete može imati višestruko značenje. Stoga je svrsishodno što zakonodavac određuje, u smislu kaznenog zakonodavstva, da je dijete osoba mlađa od četrnaest godina i time izbjegava brojne probleme koji se mogu pojaviti u konkretnom slučaju.

Logičko tumačenje obično slijedi odmah nakon jezičnog. Smisao je logičkog tumačenja da se pomoću pravila logike utvrdi smisao pravne norme ili barem da se eliminiraju pojedina od mogućih značenja koja bi bila suprotna zakonima logike. Pravni sustav upravo pomoću zakonitosti logike nastoji ostvariti višu razinu koherentnosti sa što manje kontradiktornosti unutar sebe. U pravila logičkog tumačenje uobičajeno se svrstavaju: ${ }^{26}$ argumentum a contrario - „argument kojim se iz jedne izričite normativne kvalifikacije nekog ponašanja zaključuje da postoji

le pravnu izobrazbu i obuku. Vidi: KREGAR, J., Legitimnost prava, Studia lexicographica: časopis za leksikografiju i enciklopedistiku, vol. 5, br. 1 (8), Zagreb, 2011., str. 17. - 43., dostupno na: https://hrcak.srce.hr/110266 (26. 1. 2020.).

24 Vidi: VISKOVIĆ, N., op. cit., str. 246. - 260.

Kazneni zakon Federacije Bosne i Hercegovine, Službene novine Federacije BiH, br. 36/2003, 21/2004 - ispr., 69/2004, 18/2005, 42/2010, 42/2011, 59/2014, 76/2014, 46/2016 i $75 / 2017$. 
suprotna prešutna kvalifikacija drugog ponašanja;“27 argument analogije - zaključivanje po sličnosti, „argument kojim se iz jedne izričite kvalifikacije (ovlaštenja, obveze) nekog odnosa zaključuje da ista kvalifikacija pripada i drugom odnosu koji je bitno sličan ovome izričito kvalificiranom;“28 i

argumentum a fortiori - razlikuju se dvije podvrste ovog pravila: argumentum a minori ad maius (zaključivanje od manjeg na veće, primjerice tko odgovora za djelo počinjeno iz nehata, odgovarat će i za namjerno počinjeno djelo) $i$ argumentum a maiori ad minus (zaključivanje od većeg na manje, „subjekt kojemu pravna norma daje veća ovlaštenja ili obveze ima tim prije i sva ona uža ovlaštenja i obveze koji su uključeni u one veće ${ }^{(29}$ ). Visković smatra da ova pravila ne bi trebalo podvesti pod logičko tumačenje budući da se sva ova pravila „mogu pobijati s gledišta nekog drugog cilja i drugog argumentativnog zaključivanja. “30

O sistemskom tumačenju kao utvrđivanju cijele norme smisaonim povezivanjem pojedinih elemenata norme sadržane u različitim pravnim odredbama već smo govorili. Na ovom mjestu je potrebno reći da postoji i druga vrsta ovog tumačenja koja podrazumijeva da se smisao pravne norme otkriva pomoću mjesta koje norma zauzima u općem sustavu pravnih normi. ${ }^{31}$

Ciljno ili teleološko tumačenje zauzima centralno mjesto u sustavu pravila tumačenja. ${ }^{32}$ Primjenom ciljnog tumačenja otkriva se smisao pravne norme analizom cilja koji se želi ostvariti tom normom. Drugim riječima, utvrđuje se razlog postojanja pravne norme, ratio legis, a zatim se iz toga razloga otkriva sadržaj pravne norme. Koji cilj se ima na umu kada se govori o ciljnom tumačenju? ${ }^{33} \mathrm{Je}$ li to cilj koji je imao na umu tvorac norme u trenutku njezinog stvaranja ili cilj koji pravna norma treba ostvariti u trenutnom stupnju razvoja društvene zajednice?

$27 \quad$ Ibid., str. 255.

28 Loc. cit.

$29 \quad$ Ibid, str. 256.

Ibid., str. 257.

O dometima i značaju sistemskog tumačenja vidi više: HARAŠIĆ, Ž., Dometi sistematskog tumačenja u pravu, Zbornik radova Pravnog fakulteta u Splitu, vol. 46, br. 2, Split, 2009., str. 315. - 335., dostupno na: https://hrcak.srce.hr/38207 (26. 1. 2020.).

Poseban znanstveni doprinos analizi ciljnog tumačenja dala je prof. Žaklina Harašić u radu Još o teleološkoj argumentaciji. Vidi: HARAŠIĆ, Ž., More about teleological argumentation in law, Pravni vjesnik, vol. 34, br. 3 - 4, Osijek, 2015., str. 23. - 50., dostupno na: https://hrcak.srce.hr/155851 (27. 1. 2020.).

Važan doprinos analizi ove teme dao je Marmor u djelu Interpretation and Legal Theory. Vidi više: MARMOR, A., Interpretation and Legal Theory, Hart Publishing, Oxford and Portland, 2005., str. 119. - 139. 
Ovisno o odgovoru na ovo pitanje razlikuju se subjektivno i objektivno ciljno tumačenje. Subjektivnim tumačenjem utvrđuje se značenje pravne norme utvrđujući cilj tvorca norme u trenutku stvaranja. Objektivno je ono tumačenje kojim se između više mogućih značenja pravne norme odabire ono značenje koje odgovara aktualnim ciljevima društva. ${ }^{34}$ Autor ovog rada priklanja se potonjem iz nekoliko razloga. Pravna norma uvijek je apstraktna. Ona ne uređuje pojedinačne odnose zbog nemogućnosti normotvorca predvidjeti sve moguće činjenice na koje će se norma primijeniti. Upravo je zadatak onoga tko tumači pravnu normu određeno činjenično stanje koje se dogodilo neposredno prije tumačenja podvesti pod pravnu kvalifikaciju pravne norme koja je nastala ranije od činjeničnog stanja. Drugi argument u prilog primjene objektivnog ciljnog tumačenja nužnost je pravnog sustava da bude fleksibilan. Pravni sustav nije nekakav savršeni i konačni skup normi. Ne može se pravnim aktom predvidjeti svaka životna situacija koja će zahtijevati pravnu kvalifikaciju. Svakako je potrebno pravnu normu tumačiti sukladno aktualnim ciljevima društva. U suprotnom, norma će izgubiti valjanost zbog odbacivanja adresata pravne norme da se ponašaju na način propisan u normi. Subjektivno tumačenje odgovaralo je starijim pravnim sustavima u kojima je nužno bilo uvesti strogi formalizam. Danas bi njegova primjena kočila razvoj prava jer pravna norma donošenjem tek ulazi u pravni sustav. Ona se kasnijim tumačenjem i primjenom razvija, dostvarava, nadopunjuje i na takav način zadržava svoju valjanost u promjenjivim društvenim odnosima.

Povijesno tumačenje ima karakteristiku pomoćnog pravila tumačenja. Sastoji se u ispitivanju povijesnih okolnosti koje su prethodile donošenju pravne norme kako bi se utvrdio razlog donošenja, occasio legis. ${ }^{35}$ Slično je subjektivnom ciljnom tumačenju, ali nekada može biti korisno dodatno pravilo pri primjeni objektivnog tumačenja kada je za otkrivanje najboljeg značenja pravne norme potrebno utvrditi dublje razloge njezina donošenja. ${ }^{36}$

$34 \quad$ Vidi: VISKOVIĆ, N., op. cit., str. 250.

35 Pađen navodi da su svi hrvatski teoretičari prava koji su djelovali nakon što je teorija prava postala temeljnom disciplinom pravnog studija (Perić, Miličić, Visković, Vrban, Pokrovac i Pađen) bili skloni da pravo pojme historijski, kao uvjetovano društvenim okolnostima. Sukladno takvoj sklonosti značenje pravnih izraza nije moguće odvojiti od vladajuće volje čiji su izraz; jezično i logično tumačenje pravnog izraza nije moguće odvojiti od svrhovitoga, a potonje od subjektivnoga; objektivno tumačenje je samo jedno od subjektivnih tumačenja, i to ono koje je trenutačno najutjecajnije; to što se drži vladajućom voljom jedna je od mnoštva djelatnih volja s relativno najvećim utjecajem. Vidi: PAĐEN, I., Pouke pravnog monizma - povodom Marijan Pavčnik, Teorija prava: prispevek razumevanju prava, 5. pregledano i dopunjeno izdanje s novim poglavljem Aleša Novaka, Zbornik Pravnog fakulteta u Zagrebu, vol. 66, br. 5, Zagreb, 2016., str. 595. - 617., dostupno na: https://hrcak.srce.hr/169097 (27. 1. 2020.). 
Doslovno, prošireno (ekstenzivno) i suženo (restriktivno) tumačenje odnose se na adekvatnost korištenja izraza od strane normotvorca $u$ formuliranju pravne norme. U većini slučajeva bit će dostatno doslovno tumačenje. Međutim, neke životne situacije zahtijevaju restriktivno ili ekstenzivno tumačenje pravne norme. U prethodno spomenutoj normi definicije koja propisuje da je dijete osoba koja nije navršila četrnaest godina evidentno je da takvu normu treba doslovno protumačiti. Kad ne bi postojala takva norma, ekstenzivnim tumačenjem moglo bi se zaključiti da se izraz dijete odnosi na osobe koje nisu punoljetne. Ili pak, u obiteljskopravnom kontekstu moglo bi se utvrđivati odnosi li se izraz dijete na osobe rođene u braku ili izvan braka, odnosi li se, u smislu uzdržavanja, na djecu koja nisu punoljetna ili i na osobu koja je punoljetna ali se redovito školuje. Sva ova pitanja ukazuju da će biti potrebno primijeniti ono tumačenje koje najbolje odgovara cilju norme koji ona ima u trenutnim društvenim odnosima.

Guastini navodi drugu kvalifikaciju tumačenja. Razlikuje spoznajno, odlučujuće i stvaralačko tumačenje. Spoznajno ili kognitivno tumačenje sastoji se u „utvrđivanju različitih mogućih značenja normativnog teksta, pri tome ne izabirući nijedno od njih. ${ }^{“ 37}$ Odlučujuće ili decizivno tumačenje „sastoji se u izboru određenog značenja odbacujući preostala. ${ }^{\text {“3 }}$ Stvaralačko ili kreativno tumačenje „sastoji se u pripisivanju tekstu novog značenja koje nije obuhvaćeno onima utvrdivima u okviru spoznajnog tumačenja. “" ${ }^{39}, 40$ Ova klasifikacija odnosi se na vrste mogućeg tumačenja u smislu rezultata tog procesa prije nego li na pravila koja valja primijeniti u otkrivanju najboljeg značenja pravne norme.

Između navedenih metoda tumačenja ne postoji hijerarhijski odnos koji bi ukazivao koju metodu treba smatrati najvišom, najvrjednijom u sustavu metoda. Zbog ove činjenice Visković ih ne naziva više metodama, nego samo pravilima tumačenja, dok Kelsen smatra da „naprosto ne postoji metoda, a da bi se mogla karakterizirati kao pozitivnopravna, po kojoj bi se od više jezičnih značenja

GUASTINI, R., op. cit., str. 354. - 355.

Ibid, str. 355.

Loc. cit.

Pojedini autori stvaralačko tumačenje klasificiraju drukčije. Tako Simović navodi tumačenje pravnih praznina (lacuna iuris) kao posebnu vrstu tumačenja, odnosno rješavanja pitanja koja nisu striktno regulirana normama sadržanim u odgovarajućim izvorima prava. Ovakvo tumačenje ima izrazito kreativni karakter, jer se ono, u stvari, po pravilu, svodi na stvaranje određenih normi, koje inače ne postoje u odnosu na određeno pravno pitanje. Vidi više: SIMOVIĆ, M., SIMOVIĆ, M., Pojam i značenje tumačenja pravnih normi u Bosni i Hercegovini, Anali Pravnog fakulteta Univerziteta u Zenici, god. 5, br. 9., Zenica, 2012., str. 9. - 28., dostupno na: http://prf.unze.ba/Docs/Anali/godina_5_broj_9/M_Simovic.pdf (27. 1. 2020.). 
neke norme samo jedno moglo odlikovati kao ispravno“. 41,42 Štoviše, neki autori, poput Guastinija, metode tumačenja smatraju jednim od izvora višeznačnosti normativnih tekstova. ${ }^{43}$

Autor smatra da metode tumačenja ne bi trebale biti izvor višeznačnosti ako se upotrebljavaju na pravilan način. Jasno je da su argumentum a contrario $i$ argumentum a simili ad simile (razlog suprotnosti i analogija) pravila tumačenja koja dovode do različitih zaključaka. Međutim, onaj tko tumači pravnu normu neće upotrijebiti oba pravila istovremeno, nego će uz pomoć drugih pravila, primjerice ciljnog tumačenja, znati koje od navedenih pravila treba primijeniti. U normi koja propisuje da punoljetni građani imaju pravo birati i biti birani, tumač će primjenom argumentum a contrario zaključiti da takvo pravo nemaju maloljetni građani. Do zaključka da u ovom slučaju treba upotrijebiti argumentum a contrario tumač može doći upotrebom ciljnog tumačenja. Ratio legis norme o pravu punoljetnih građana birati i biti birani jest u zakonodavčevoj namjeri da aktivno i pasivno biračko pravo imaju građani određenog stupnja zrelosti za sudjelovanje u izborima. S druge strane, isključenje upotrebe analogije u ovom slučaju može se postići primjenom drugih pravila, primjerice argumenta apsurdnosti. ${ }^{44}$

Iako ne postoje pravila koja određuju redoslijed primjene metoda, autor smatra da bi prilikom tumačenja metode trebalo primijeniti sljedećim redom: jezično tumačenje - logično tumačenje - sistemsko tumačenje - ciljno tumačenje kao osnovna, temeljna pravila tumačenja, te kao pomoćna ostala pravila tumačenja kada se upotrebom temeljnih ili osnovnih pravila ne može utvrditi smisao predmetne norme.

${ }^{41} \quad$ KELSEN, H., Čista ..., cit. u bilj. 9, str. 77.

42 Čini se da i Kelsen u gore navedenoj tvrdnji implicitno priznaje postojanje i značaj jezične metode kao početnog koraka u utvrđivanju pravog značenja neke norme budući da se jezičnom metodom utvrđuju moguća značenja neke norme koju ona ima u okviru jezičnog sustava nekog društva.

GUASTINI, R., op. cit., str. 362. - 363.

$44 \quad$ U suvremenoj logici, argument apsurdnosti je tehnika reduciranja argumenta ili hipoteze do apsurdnosti, podvodeći premisu ili zaključak nekog argumenta pod njegove logičke granice, pokazujući kako bi bile apsurdne posljedice takvog argumentiranja, opovrgavajući odnosno diskreditirajući upotrebu takve vrste argumentiranja u predmetnom slučaju. Vidi više: STAWECKI, T., Argument against Absurdity of Legal Reasoning - Fundamental, Subsidiary Rhetoric?, Masaryk University, Brno, 2012., str. 89. - 102., dostupno na: https://www.law.muni.cz/sborniky/argumentation2012/argumentation2012.pdf (28. 1. 2020.). 


\section{Pravne praznine}

Kada se u pravnom sustavu otkrije postojanje praznine, tumačenje iz spoznajne funkcije prelazi na složeniju razinu stvaralačke funkciju u pravnom sustavu. Što su pravne praznine? ${ }^{45} \mathrm{Na}$ to pitanje teško je dati unificiran odgovor. Zbog toga što postoji razlikovanje najmanje tri pojma pravne praznine: vrijednosne ili aksiološke praznine, normativne ili prave praznine i tehničke praznine.

Prije objašnjena navedenih pojmova potrebno je prethodno navesti kako pojedini autori isključuju mogućnost postojanja praznina. ${ }^{46}$ Radi se o takozvanom načelu slobode odnosno općoj isključujućoj normi: „sve što izrijekom nije zabranjeno, prešutno je dopušteno. ${ }^{\text {" } 77}$ Primjenom takve norme ne bi postajalo pravno nekvalificirano ponašanje. Onaj tko primjenjuje pravo u konkretnom slučaju, na temelju takve norme može riješiti svaki spor. Postoje pravno zabranjena ponašanja. Svako drugo ponašanje pripada u područje slobode kao temeljnog egzistencijalnog sastojka čovjekova djelovanja. Očigledno je da ova norma ima cilj zatvaranje pravnog poretka.

U ovom smislu značajno je navesti Kelsenovo stajalište. Prema Kelsenu, „ne postoje prave praznine $\mathrm{u}$ tom smislu da se neki pravni spor ne bi mogao riješiti na temelju vrijedećih ${ }^{48}$ normi zato što se zakon ne može primijeniti jer nedostaje propis koji bi se odnosio na dani slučaj. Svaki se pravni spor sastoji u tome da jedna strana postavlja neki zahtjev protiv druge, a odluka kojom se taj zahtjev prihvaća ili odbacuje ovisi o tome određuje li neka vrijedeća pravna norma koja

45 Prema jednom mišljenju, teški slučajevi o kojima se raspravlja kasnije, tzv. hard cases odnose se na pravnu prazninu u pravnom sustavu, u smislu da pravna pravila propuštaju propisati koje ponašanje je pravno dopušteno ili pravno zabranjeno. Vidi: SOPPER, E. P., Legal Theory and the Obligation of a Judge: The Hart/Dworkin Dispute, Michigan Law Review, vol. 75, br. 3, Ann Arbor, 1977., str. 473. - 519., dostupno na: https://repository. law.umich.edu/mlr/vol75/iss3/2 (28. 1. 2020.).

Među brojnim kritičarima teze o nepostojanju pravnih praznina, čini se da je najradikalnija ona koju iznosi Herman U. Kantorowicz u djelu Kampf. Tako Pokrovac navodi da je „na rasplamsavanje diskusije, ali ništa manje i na Kantorowiczev dalji rad, presudno utjecala radikalnost teza o lakunoznosti zakona i prava u Kampfu. Na ove teze su se pozivali i pozivaju i oni koji su pokret i Kantorowicza htjeli kompromitirati i oni koji su ih podržavali, a postale su i obvezno i najčešće mjesto istraživačke lektire."Vidi: POKROVAC, Z., Slobodno stvaranje prava, Herman U. Kantorowicz i slobodnopravni pokret, Naklada Breza, Zagreb, 2018., str. 244.

Kelsen razlikuje valjanost i učinkovitost pravne norme. On smatra da je neka norma valjana, iako može biti neučinkovita, ukoliko takva norma ima mjesto u tvorbenoj svezi valjanog poretka. Ovakvo razlikovanje može se usporediti s Viskovićevim razlikovanjem formalnog i materijalnog važenja pravne norme. 
se primjenjuje na konkretan slučaj pravnu obvezu za koju se tvrdi da postoji. Budući da nema treće mogućnosti, odluka je uvijek moguća, i to uvijek na temelju zakona, to jest njegovom primjenom. I u odluci kojom se zahtjev odbacuje primjenjuje se vrijedeći pravni poredak. Jer time što ljude obvezuje na sasvim određeno ponašanje, on $s$ druge strane tih pravnih obveza jamči slobodu. " ${ }^{49}$ Prema tome, za Kelsena tumačenje počinje tek s normama čije je postojanje potvrđeno, proces tumačenja nema utjecaja na stvaranje pravne norme. ${ }^{50}$

Opća isključujuća norma danas se primjenjuje na području kaznenog zakonodavstva kroz pravilo nullum crimen, nulla poena, sine lege. ${ }^{51} \mathrm{U}$ onim područjima pravnog sustava koji ne sadrže spomenutu normu, ponašanje koje nije izrijekom zabranjeno niti dopušteno pravno je nekvalificirano i kao takvo predstavlja prazninu.

Normativna ili prava praznina označava odnos koji je važan za opstanak i dobrobit društva, sadrži snažne sukobe interesa i izvanjski je kontrolabilan, što upućuje na potrebu njegovog normiranja, ali koji ipak ostaje pravno nenormiran ili nedostatno normiran. ${ }^{52}$ Guastini izražava stav da pravne praznine ne prethode tumačenju nego slijede po izvršenom tumačenju: „Pravna praznina zapravo ne otvara tumačenjski problem, nego problem druge naravi. $S$ jedne strane, ako i kada se pojavi praznina, tumačenje je već izvršeno (bez obzira na mogućnost odbacivanja izabranog tumačenja i opredjeljivanja za drugačije tumačenje kojim se praznina izbjegava). ${ }^{“ 53,54}$

Tehnička praznina označava slabo normativno reguliranje ili zbog nedostajanja nekog važnog elementa norme ili zbog nejasnoća pojmova kojima se norma iskazuje. Ona postoji kad u pravnom poretku nedostaje norma čije je postojanje nužni uvjet sposobnosti djelovanja neke druge norme.$^{55}$ Kelsen niječe postojanje praznina u gore spomenutom smislu, ali priznaje mogućnost postojanja tehničkih praznina.

KELSEN, H., Čista ..., cit. u bilj. 9, str. 79. - 80.

Vidi: VILLA, V., A Pragmatically Oriented Theory of Legal Interpretation, Journal for constitutional theory and philosophy of law, No. 12, Kranj, 2010., str. 89. - 120., dostupno na: https://journals.openedition.org/revus/146 (22. 5. 2020.).

Vidi PETROVIĆ, B., JOVAŠEVIĆ, D., FERHATOVIĆ, A., Krivično pravo I., Pravni fakultet Univerziteta u Sarajevu, Sarajevo, 2015., str. 22. - 23.

VISKOVIĆ, N., op. cit., str. 233.

GUASTINI, R., op. cit., str. 371.

Suprotan stav iznosi Stefanović koji navodi da praznina kao normativno pravna pojava postoji neovisno od saznanja za nju. Vidi STEFANOVIĆ, Z., Identifikacija pravnih praznina, Pravni zapisi, god. IV., br. 1, Beograd, 2013., str. 5. - 26., dostupno na: http://www. pravnizapisi.rs/svi-brojevi/pravni-zapisi-1-20 (28. 1. 2020.).

VISKOVIĆ, N., op. cit., str. 235. 
Vrijednosna praznina označava sud nekog subjekta da je postojeća norma nepravedna odnosno vrijednosno pogrešna. Tu nije riječ o prazninama u pravom smislu, one se ne odnose na pozitivni pravni poredak. Zapravo ta vrsta praznina kritizira pozitivnopravni poredak ili neku njegovu normu i govori o tome kakvo bi pravo trebalo biti de lege ferenda. ${ }^{56,57}$

Iz prethodno navedenog razvidno je da u svakom pravnom sustavu postoje praznine. Iako praznine postoje u pravnom sustavu, u suvremenim pravnim porecima općenito vrijedi načelo zabrane uskrate pravosuđa, non liquet. Stoga, praznina se mora popuniti i ne može se odbiti rješavanje pravnog spora pozivom na činjenicu da u pravnom sustavu nije normirano činjenično stanje, odnosno nije normiran jedan važni konfliktni odnos. Suci moraju primjenom pravno dopuštenih metoda popuniti prazninu. Međutim, jasno je da sudska funkcija time dobiva neke elemente zakonodavstva. Gdje je granica između sudstva i zakonodavstva koja se ne smije prijeći u popunjavanju praznina? U kakvom su odnosu popunjavanje pravnih praznina i načelo zakonitosti?

\subsection{Popunjavanje pravnih praznina}

Kada se u pravnom sustavu utvrdi postojanje praznina, moguća su dva rješenja. Prvo, moguće je da zakonodavac prepozna postojanje praznine, utvrdi važnost reguliranja konfliktnog odnosa i zakonodavnom intervencijom otkloni prazninu iz pravnog sustava. Ipak, iako je prvi sustav rješavanja praznina poželjan, zbilja pokazuje da praznine češće uklanjaju sudovi i upravna tijela individualnim pravnim aktima. Tumaču/primjenjivaču pravne norme stoje na raspolaganju različita sredstva popunjavanja pravnih praznina i nadilaženja spornih situacija: analogija, razlog suprotnosti, tumačenje izuzetaka (exceptiones non sunt extendendae ${ }^{58}$ ) te korištenje općih načela kao metode popunjavanja pravnih praznina. ${ }^{59}$

56 Vidi: GUASTINI, R., Defeasibility, Axiological Gaps, and Interpretation, Journal for consitutional theory and philosophy of law, No. 14, Kranj, 2010., str. 39. - 56., dostupno na: https://journals.openedition.org/revus/1332?gathStatIcon=true\&lang=hr (21. 5. 2020.).

Peczenik razlikuje četiri vrste praznina: praznine koje su posljedica nedovoljnog reguliranja (an insuficiency gap), praznine koje su posljedica nedosljednosti (an inconsistency gap), praznine koje su posljedica neodređenosti (an indeterminacy gap) te vrijednosne praznine (an axiological gap). Vidi: PECZENIK, A., On Law and Reason, Springer, Lund University, 2008., str. 18.

U procesu primjene pravne norme tumač se može ponekad susresti s normom koja je izuzetak u odnosu na opću pravnu normu. Tada takav izuzetak tumač treba tumačiti usko. Vidi: HASIĆ, Z., Osnovi prava - Uvod u nauku o državi i pravu, Des, Sarajevo, 2004., str. 245. 
O analogiji kao pravilu tumačenja govoreno je ranije u tekstu. Analogija kao način popunjavanja praznina ${ }^{60}$ zasniva se na pretpostavci ako su dva predmeta, dva odnosa slična u nekim važnim osobinama, može se zaključiti o njihovoj sličnosti i u drugim njihovim osobinama. Pri tome, obično se koristi pravni standard bitna sličnost. Što se podrazumijeva pod tim pravnim standardom? Visković smatra da se „pod bitnom sličnošću, kao uvjetom primjene analogije u pravu, misli prvenstveno na identičnost interesa i ciljeva (ratio legis) koji se pravnom normom štite. Oba odnosa, onaj normirani i onaj nenormirani, moraju biti na isti način sporni, vrijedni i svrhoviti sa stajališta pravnog sustava odnosno subjekta koji odlučuje o popunjavanju praznine. ${ }^{\text {61 } 1}$

Kod primjene analogije za popunjavanje pravnih praznina, valja razlikovati zakonsku i pravnu analogiju. ${ }^{62}$ Zakonska analogija ili analogia legis je ona vrsta analogije koju koristi tumač primjenjujući jednu pravnu normu na konkretan pravni slučaj. Pri tome, kod djelomične analogije (analogiae partialis) popunjavanje se vrši tako da se iz nekoliko posebnih normi stvori rješenje za otklanjanje praznine, dok se kod potpune analogije (analogiae totalis) do zaključka kojim se otklanja praznina dolazi analizom ciljeva i osobnosti cjelokupnog prava. Pravna analogija ili analogia iuris sastoji se u primjeni jednog ili više općih načela koji važe u nekom pravnom sustavu da bi se njihovom konkretizacijom stvorilo pravilo koje rješava prazninu. ${ }^{63}$

$\mathrm{Na}$ osnovi navedenog može se zaključiti da postoje različita pravila koja tumaču pomažu da utvrdi pravo značenje neke sporne norme. Međutim, kada tumač ili

60 Perić navodi četiri načina popunjavanja praznina: zakonodavnu intervenciju, primjenu običajnog prava, stvaranje norme i analogiju. Zanimljivo je da ovaj autor izdvaja analogiju kao poseban način popunjavanja praznina razlikujući ga od stvaranja norme. Čini nam se ipak da je primjena analogije uvijek na određen način, stvaranje ili nadopunjavanje postojeće norme. Iako se analogija od čistog stvaranja prava razlikuje primjenom pravnog standarda bitne sličnosti, odnosno primjene jedne norme na odnos koji nije reguliran, a bitno je sličan onom odnosu koji je reguliran normom na koju će se primjenjivač norme pozvati, ipak autor smatra da ovakva klasifikacija nije najbolja i da nema potrebe izdvajati analogiju od stvaranja norme kao načina popunjavanja pravne praznine. Vidi: PERIĆ, B., Država i pravni sustav, Informator, Zagreb, 1994., str. 225. - 226. VISKOVIĆ, N., op. cit., str. 263.

Neki autori vrše klasifikaciju analogije na deskriptivnu i normativnu analogiju. Bitna karakteristika deskriptivne analogije sastoji se u tome da su stajalište koje se brani i razlog kojim se opravdava stajalište deskriptivni. Za normativnu analogiju je bitno načelo konzistencije koje zahtijeva da se stvari, situacije, osobe ili institucije koje pripadaju istoj kategoriji trebaju tretirati na isti način: Vidi više: HARAŠIĆ, Ž., Analogija u pravu: značenje i upotreba, Pravni vjesnik, vol. 34, br. 3 - 4, Osijek, 2018., str. 177. - 202., dostupno na: https://hrcak.srce.hr/214254 (28. 1. 2020.). 
onaj tko primjenjuje pravnu normu utvrdi postojanje praznine, on tu prazninu ne može otkloniti tumačenjem u užem, spoznajnom smislu. On tada treba posegnuti za stvaralačkim tumačenjem koje neki autori nazivaju i pravno konstruiranje budući da se stvara nova, do tada nepostojeća norma. Kakav je odnos te novostvorene norme s načelom zakonitosti? Prethodno je potrebno objasniti značenje načela zakonitosti.

\section{Načelo zakonitosti}

Pravna načela predstavljaju temelj svakog pravnog sustava. Pojam načela objedinjuje u sebi dvije komponente: temeljni karakter i stanoviti stupanj neodređenosti. Prema Miličiću, „načela jesu i trebaju biti srž, potpunost, sublimacija, vrijednosna osnova, najviši izričaj svekolikih vrijednosnih sadržaja, zbiljskih i mogućih vrijednosti u pravu. “" ${ }^{44}$ opća pravna načela ubraja se svakako i načelo zakonitosti. „Pravni poredak predstavljao bi nepregledan i neusklađen niz općih i pojedinačnih pravnih normi i akata kada ne bi bio uređen po nekom unutarnjem načelu koje bi sve njegove dijelove povezivalo u jedinstvenu i neproturječnu cjelinu i omogućavalo mu da djeluje kao efikasna materijalna i duhovna društvena snaga nad egzistencijom društva i čovjeka." ${ }^{65}$ Pravni sustav osigurava jedinstvo lišeno antinomija na temelju argumenta koherentnosti. ${ }^{66}$ Argument koherentnosti „organima dopušta da opravdavaju održanje najvećeg mogućeg broja zakonodavnih akata i ujedno da odstranjuju najmanji mogući broj istih zbog razloga inkompatibilnosti. “67

Prema Viskoviću „načelo zakonitosti je temeljna norma pravnog sustava koja zahtijeva da svi pravni akti državnih i drugih subjekata, kao i njihove pravne

$64 \quad$ MILIČIĆ, V., op. cit., str. 117.

65 MUHIĆ, F., op. cit., str. 311.

Koherentnost pravnog sustava ima djelomično sličan cilj kao i zakonitost: osigurati da niže pravne norme budu formalno i materijalno zakonite, odnosno da se iz pravnog sustava otklone antinomije. Sredstva za uklanjanje antinomija izražena su kroz latinske maksime: lex superior derogat legi inferiori - u slučaju sukoba između normi višeg i nižeg hijerarhijskog položaja primijenit će se viša norma; lex posterior derogat legi priori - u slučaju sukoba između dvije norme, kasnija u smislu vremena donošenja ukida raniju normu; lex specialis derogat legi generali - u slučaju sukoba specijalne i opće norme primijenit će se specijalna norma koja uređuje posebnu podvrstu nekog odnosa o kojem postoji sukob. Vidi: HARAŠIĆ, Ž., Zakonitost kao pravno načelo i pravni argument, Zbornik radova Pravnog fakulteta u Splitu, vol. 47, br. 3, Split, 2010., str. 745. - 767., dostupno na: https:// hrcak.srce.hr/59766 (29. 1. 2020.). 
radnje, budu formalno i materijalno usklađeni s višim pravnim normama koje reguliraju iste odnose, propisujući sankcije protiv akata i radnji koji taj zahtjev ne poštuju. “68 Iz ove definicije jasno proizlazi da se razlikuju dvije vrste zakonitosti: formalna i materijalna zakonitost. Formalna zakonitost je zahtjev o nadležnosti, postupku i obliku. Ona traži da svi niži akti budu doneseni od nadležnih organa koji su kao takvi određeni višim aktima, da se niži akti donose po proceduri i u postupku propisanim višim aktima i da svi akti budu doneseni u onoj formi koja je određena višim aktom. Materijalna zakonitost je zahtjev o sadržaju. Sadržaj nižih pravnih akata mora biti sukladan sadržaju viših pravnih akata koji uređuju istu vrstu društvenih odnosa.

Za utvrđivanje nezakonitosti akta u pravilu je nadležan organ „koji donosi akt koji je hijerarhijski jači od akta čija se zakonitost ispituje, odnosno onaj organ koji ima viši položaj na hijerarhijskoj ljestvici državnih organa od organa čiji se akt ispituje. "69 Ako se u pravnom sustavu pojavi neki akt koji je formalno ili materijalno nezakonit, isti će se u postupku ispitivanja zakonitosti ukloniti. Međutim, nezakonit akt može postojati u pravnom sustavu. Sve dok se ne utvrdi po propisanom postupku od nadležnog državnog organa, takav akt objektivno postoji u pravnom sustavu. Pitanje utvrđivanja nezakonitosti jasnije je kada se radi o formalno nezakonitim aktima, onim aktima u kojima je sadržana povreda pravila o nadležnosti, postupku i/ili obliku. Zbog toga jer su pitanja nadležnosti, postupka i oblika izričito propisana u višim pravnim aktima i njihovo nepoštivanje, ako se pojavi, očigledno je. Drukčije je kad se radi o materijalnoj nezakonitosti zbog činjenice da je nepoštivanje više norme u odnosu na sadržaj teže utvrditi, takva nezakonitost nije odnosno ne mora biti očita.

\subsection{Odnos načela zakonitosti i stvaralačkog tumačenja}

Odnos između načela zakonitosti i tumačenja nije sporan kada se tumačenjem utvrđuje i odabire jedno od mogućih značenja neke pravne norme. Poštovanje načela zakonitosti može se provjeriti analizirajući odnos tumačene norme i neke više norme koja uređuje istu materiju. Taj odnos postaje sporan i konfuzan kada se pokuša analizirati odnos između norme koja do tada nije postojala $\mathrm{u}$ pravnom sustavu, nego je stvorena stvaralačkim tumačenjem, i načela zakonitosti. Drugim riječima, sporan je odnos koji nastaje otkrivanjem pravne praznine i vladavine prava u konkretnom pravnom sustavu.

Problematika tumačenja i razlikovanja slučajeva kad se tumačenjem utvrđuju moguća značenja neke pravne norme i izabire najpogodnije značenje i slučaje-

68 VISKOVIĆ, N., op. cit., str. 180.

69 PERIĆ, B., Struktura prava, Narodne novine Zagreb, 1968., str. 113. 
va $\mathrm{u}$ kojima se tumač susreće s problemom nedovoljne pravne definiranosti $\mathrm{u}$ komparativnoj se pravnoj teoriji može usporediti s razlikovanjem između teških slučajeva (hard cases) i jednostavnih slučajeva (easy cases). ${ }^{70,71}$ Ovo se razlikovanje vezuje uz jednog od najznačajnijih pravnih teoretičara H. L. A. Harta. Dok su jednostavni slučajevi nesporni, problem se pojavljuje kod teških slučajeva. Kako Harašić navodi, takvi slučajevi „zahtijevaju primjenu pravila interpretacije koja ne uključuju jednostavnu primjenu samo pravnih normi, već i razmatranje drugih - nepravnih temelja, npr. moralnih i političkih. To znači da u tim 'teškim slučajevima' suci imaju diskreciju i stvaraju novo pravo. ${ }^{\text {"72 }} \mathrm{Za}$ razliku od Harta, po Dworkinu, pravo nije samo sustav pravnih normi, nego se sastoji i od drugih standarda, pravnih principa i pravnih politika. Teške slučajeve treba riješiti tako što će sudac utemeljiti odluku na pravnim principima. ${ }^{73}$ Zbog mogućnosti primjene pravnih principa otpada potreba za diskrecijom sudaca. ${ }^{74}$

Kada se sudac ili druga osoba ovlaštena primijeniti pravnu normu susretne s pravnom prazninom, na raspolaganju ima dvije mogućnosti. Prvo, može utvrditi da konkretni odnos nije pravno reguliran te kao takav pripada u pravno prazan prostor. Sukladno ovakvom deduciranju, sudac bi utvrdio da se konkretno činjenično stanje ne može podvesti ni pod jednu važeću normu. Posljedica ovog zaključivanja dovela bi ili do uskrate pravosuđa, a ranije smo utvrdili da u modernim pravnim sustavima vrijedi zabrana uskrate pravosuđa, ili bi sudac primjenom argumenta a contrario zaključio da takvo ponašanje nije izričito propisano, stoga je slobodno. Ovakav stav izravni je rezultat dogme o potpunosti pravnog sustava prema kojoj nema pravnih praznina te sudac može riješiti svaki pravni spor primjenom pozitivnog prava (ako ponašanje koje je predmet zahtjeva nije pravno regulirano, zahtjev je jedino moguće odbiti). ${ }^{75}$

70 Neki autori koriste drukčije nazive. Aarnio tzv. lake slučajeve naziva rutinskim, običnim slučajevima (routine cases) u kojima će sudac donijeti odluku mehanički, rutinski za razliku od teških slučajeva koje naziva hard cases i u kojima sudac donosi odluku po diskreciji. Vidi: AARNIO, A., The Rational as Reasonable, A Treatise of Legal Justification, D.Reidel Publishing Company, Dordrecht, 1987., str. 2. MacCormick za lake slučajeva koristi naziv clear cases. Prema ovom autoru, nema jasne linije razgraničenja lakih i teških slučajeva. Vidi više: MACCORMICK, N., Legal reasoning and legal theory, Clarendon Press, Oxford, 1994., str. 195. - 228. (hard cases), Zbornik Pravnog fakulteta u Zagrebu, vol. 56, br. 1, Zagreb, 2006., str. 85. 116., dostupno na: https://hrcak.srce.hr/5131 (30. 1. 2020.).

Ibid, str. 88 .

Ibid, str. 89.

75 Vidi više: GUASTINI, R., op. cit., str. 378. - 381. 
Drugo, sudac odnosno primjenjivač norme može posegnuti za stvaralačkim tumačenjem i pravni spor riješiti uvođenjem u pravni sustav nove, neizražene pravne norme. Međutim, ovakvim tumačenjem sudac postaje neka vrsta apokrifnog zakonodavca. On stvara novu pravnu normu koja će se primijeniti unatražno na činjenično stanje nastalo prije postojanja norme. Zanimljiv stav iznosi Guastini: „Ako već sama interpretacija nije kognitivna, nego odlučujuća djelatnost; onda je, tim prije, i stvaranje prava odlučujuća djelatnost. U stvari, stvaranje prava je izvorna nomopoietička djelatnost sudaca i drugih pravnika: 'zakonodavstvo u međuprostoru', kako se obično naziva. " ${ }^{\text {"6 }}$ Očigledno je da ova druga mogućnost popunjavanja pravnih praznina dolazi u sukob s nekoliko važnih načela: načelom zabrane retroaktivnosti, načelom pravne sigurnosti i načelom diobe vlasti, a posredno is načelom zakonitosti u širem smislu.

Načelo zabrane retroaktivnosti podrazumijeva zabranu primjena neke pravne norme na činjenično stanje koje je nastalo prije nego što je pravna norma donesena. Najčešće se primjenjuje na području kaznenog prava, ali ima velik značaj za cjelokupni sustav zbog pravne sigurnosti adresata pravne norme.

Pravna sigurnost je vrijednost jednog pravnog sustava koja se sastoji u predvidljivosti pravnih obveza, pravnih ovlaštenja, pravnih sankcija i određenja delikta koji su sadržani u pravnoj normi. Za neki pravni sustav kažemo da se u njemu ostvaruje pravna sigurnost ako su adresati pravne norme u mogućnosti unaprijed predvidjeti svoje obveze i ovlasti, znati koja su ponašanja kvalificirana kao delikti i kakva je sankcija propisana za počinjenje delikta. ${ }^{77}$ Visković navodi da „pravna sigurnost postoji ako donošenje i primjena pravnih normi nisu nestručni ili samovoljni akti, tj. ako nisu plod nečijih uskih ili trenutačnih interesa i volja, nego su rezultat institucionalizirane ili relativno trajne volje normotvoraca, npr. parlamenta i vlade, koja izražava za društvo reprezentativne i stabilne interese, spoznaje i očekivanja." ${ }^{\text {"78 }}$

Načelo diobe vlasti objedinjuje dvije temeljne koncepcije. Prvu, prema kojoj načelo diobe vlasti traži potpunu međusobnu ustrojbenu i funkcionalnu neovisnost triju vlasti: zakonodavne, izvršne i sudske, pri čemu ustrojbena neovisnost podrazumijeva da tijela jedne vlasti ne proizlaze iz tijela drugih vlasti, odnosno da ne smiju biti birani ili postavljeni od tijela drugih vlasti, već da svaki od njih ima posve neovisnu osnovu oblikovanja dok funkcionalna neovisnost traži potpunu samostalnost u obavljanju djelokruga tijela svake vlasti. Po drugoj koncepciji,

76 GUASTINI, R., Legal Realism Restated, Journal for constituional theory and philosophy of law, No. 19., Kranj, 2013., str. 83. - 96., dostupno na: https://journals.openedition.org/ revus/2407 (22. 5. 2020.).

77 VISKOVIĆ, N., op. cit., str. 148.

78 Ibid., str. 148. 
svrha je primjene diobe vlasti sprječavanje koncentracije ovlasti i političke moći jednog tijela. Bit je ove koncepcije u shvaćanju diobe vlasti kao dodjeljivanje osnovnih državnih funkcija različitim državnim tijelima. ${ }^{79}$

Očigledno je da, kako navodi Guastini, „u pravnoj se državi sucu priječi i da izbjegne odluku i da odluči stvarajući novu normu. " ${ }^{\circ 0}$

Budući da je iz prethodne analize razvidno da je stvaralačko tumačenje u sukobu s važnim načelima, pravnom državom i vladavinom prava, postavlja se pitanje kako će sudac riješiti slučaj koji predstavlja pravnu prazninu i može li takvo rješenje biti sukladno načelu zakonitosti? Odgovor je može, primjenom općih pravnih načela. ${ }^{81}$ Takav stav zauzima većina autora koji se bave ovom problematikom. Između ostalog, Jug navodi „da se u slučaju postojanja pravnih praznina primjenjuje pravna norma koja je predviđena za neki bitno sličan slučaj (analogija). Razlikuje se zakonska analogija (analogia legis), kad se zaključak izvodi iz određenoga zakonskog propisa, i pravna analogija (analogia iuris), kad se takav zaključak izvodi iz općih pravnih načela. Vrhovni sud Republike Hrvatske u svojoj praksi koristi navedena dva načina rješavanja pravnih praznina, pa tako u obrazloženjima svojih odluka koristi u tu svrhu i pravna načela. "82 Abramović navodi da „nisu sva općeprihvaćena načela nekog pravnog sistema ujedno i moralni principi, ali su to najvećim dijelom. Tumačenje neke norme moguće je,

79 Više o načelu diobe vlasti vidi: SMERDEL, B., SOKOL, S., Ustavno pravo, Narodne novine, Zagreb, 2009., str. 329. - 332. GUASTINI, R., op. cit., str. 380. Lukić smatra da opće načelo ne otklanja prazninu. On tvrdi da slučaj koji se regulira općim načelom ne predstavlja prazninu u cijelosti, ali niz pitanja koja se u takvom slučaju postavljaju ostaje neriješen jer opće načelo ne razrađuje pojedinosti slučaja, i te pojedinosti po Lukiću predstavljaju pravnu prazninu koja se popunjava kao sve ostale praznine u pravu. Ukoliko je načelo općenitije, utoliko je i praznina koju treba popuniti veća. Autor se djelomično slaže s ovom tvrdnjom u dijelu iz kojeg proizlazi da pravno načelo treba konkretizirati i izvući pravilo, normu koja će se primijeniti u danom slučaju. Međutim, autor smatra da su pravna načela osnova za primjenu određene mjere diskrecije suca. Sudac smije upotrijebiti diskrecijsku ovlast da riješi pravnu prazninu, ali samo i pod uvjetom da takvo diskrecijsko odlučivanje ostane u okvirima općih pravnih načela na kojima se temelji pravni sustav. U protivnom, ako bi sudac imao neograničenu diskrecijsku ovlast pri rješavanju slučajeva koji predstavljaju pravne praznine, sudac bi se pretvorio u arbitrarno tijelo i apokrifnog zakonodavca. Takvim postupanjem nesumnjivo bi bila ugrožena pravna sigurnost kao temeljna vrijednost svakog pravnog sustava. Vidi: LUKIĆ, R., Uvod u pravo, Savez udruženja pravnika Jugoslavije, Beograd, 1963., str. 337.

JUG, J., Primjena pravnih načela u odlukama Vrhovnog suda Republike Hrvatske, Međunarodni znanstveni skup „Pravna načela u pravnoj teoriji i sudskom odlučivanju“, Fondacija Centar za javno pravo i Pravni fakultet Rijeka, 2014., dostupno na: http://www.fcjp.ba/ templates/ja_avian_ii_d/images/green/Jadranko_Jug.pdf (4. 2. 2020.). 
naravno, i na drugi način, koji ne mora nužno biti povezan s moralnim načelima. Međutim, kada se radi o popunjavanju pravnih praznina analogijom iuris, neizostavno će se to morati temeljiti na moralnim, i ni na kakvim drugim, načelima. Oni su, naime, jedini općeprihvaćeni u pravom, najužem smislu tog pojma. Oni su u društvu autonomno važeći, a ostali moraju biti propisani - a ako su propisani, zna se za koji su konkretan slučaj propisani. " ${ }^{83}$

Da bi se pravna praznina riješila primjenom pravnih načela, potrebno je prethodno pravno načelo konkretizirati. Konkretizirati načelo znači izvući pravilo sa zatvorenim činjeničnim stanjem koje uređuje istu vrstu predmetnih odnosa kao i pravilo koje sadrži pravnu prazninu. Na takav način, pozivom na opće pravno načelo i njegovom konkretizacijom, primjenjivač pravne norme izbjeći će prigovor preuzimanja uloge zakonodavca, zadovoljit će zahtjev koji zabranjuje uskratu pravosuđenja te će odgovoriti zahtjevima načela zakonitosti shvaćenog u širem smislu.

\subsection{Načelo zakonitosti u praksi Europskog suda za ljudska prava}

Načelo zakonitosti zaštićeno je brojnim međunarodnim dokumentima od kojih poseban značaj ima Europska konvencija za zaštitu ljudskih prava i temeljnih sloboda. ${ }^{84}$ Konvencijom se načelo zakonitosti štiti člankom 7 . Nitko se ne može smatrati krivim za kazneno djelo izvršeno činjenjem ili nečinjenjem koje, u vrijeme kada je izvršeno, nije predstavljalo kazneno djelo po unutarnjem ili

ABRAMOVIĆ, A., Općeprihvaćena načela kao kriterij za tumačenje pravne norme, Međunarodni znanstveni skup „Pravna načela u pravnoj teoriji i sudskom odlučivanju“, Fondacija Centar za javno pravo i Pravni fakultet Rijeka, 2014., dostupno na:http://www.fcjp. ba/templates/ja_avian_ii_d/images/green/Andrej_Abramovic.pdf (4. 2. 2020.).

$\mathrm{Na}$ ovom mjestu zanimljivo je navesti da je Europski sud za ljudska prava razvio posebna načela tumačenja konvencijskog teksta, od kojih su posebno značajni: načelo autonomnog tumačenja pojmova - načelo tumačenja Konvencije prema cilju i svrsi, davanjem konvencijskim pojmovima autonomnog značenja neovisno o nacionalnom; načelo živućeg instrumenta ili evolutivnog tumačenja pojmova - tumačenje Konvencije u svjetlu aktualnih uvjeta i zahtjevu da se Konvencija razvije tumačenjima Suda u cilju fleksibilizacije zaštite prava zajamčenih Konvencijom i načelo učinkovitosti - temelji se na zahtjevu da se pravima iz Konvencije osigura djelotvorna i učinkovita, a ne iluzorna i teoretska zaštita, a podrazumijeva zahtjev prema kojem se usklađenost nekog nacionalnog uređenja s Konvencijom ne može ostvariti samo zabranom određenih ponašanja, već je zbog zaštite prava pojedinca potrebno da država ugovornica poduzme neke pozitivne obveze. Vidi više: MIHELČIĆ, G., MAROCHINI ZRINSKI, M., Utjecaj konvencijskih načela tumačenja na pojedine građanskopravne institute (odabrana pitanja), Zbornik radova Pravnog fakulteta u Nišu, god. LVII, br. 78, Niš, 2018., str. 127. - 147., dostupno na: http://www.prafak.ni.ac. rs/izdavastvo/zbornik-radova/objavljeni-brojevi-zbornik.html (3. 2. 2020.). 
međunarodnom pravu. Isto tako, ne može se izreći stroža kazna od one koja je bila propisana u vrijeme kada je kazneno djelo izvršeno. Ovaj članak ne utječe na suđenje i kažnjavanje neke osobe za činjenje ili nečinjenje koje se u vrijeme izvršenja smatralo kaznenim djelom prema općim pravnim načelima koja priznaju civilizirani narodi. ${ }^{85}$ Konvencijom se štiti načelo zakonitosti na području kaznenog prava. U stavku 1. ovog članka sadržana je opća isključujuća norma, dok stavak 2. predviđa izuzetak pozivom na opća pravna načela koja priznaju civilizirani narodi, što ukazuje na činjenicu da i Konvencija priznaje poseban značaj općim pravnim načelima.

Za potrebe ovog rada zanimljivo je navesti stav Suda koji je zauzeo u predmetima koje je rješavao. U nekoliko predmeta Sud navodi da prihvaća činjenicu da se zakoni donose na način da omogućavaju opću primjenu, pa kao takvi ne mogu uvijek biti precizni. Iako je poželjno da zakon bude jasan, uvijek postoji neizbježna mogućnost da se putem sudske interpretacije zakon prilagodi potrebama društva ${ }^{86,87,88} \mathrm{U}$ tom smislu članak 7 . ne zabranjuje postupna pojašnjenja obilježja kažnjivog ponašanja kroz sudsku praksu, posebice značajna u okviru normativnog koncepta common lawa. Sud uzima u obzir da je razvoj kaznenog prava u okviru sudske interpretacije važan dio pravne tradicije u većini država članica ${ }^{89}$ Razmatrajući pitanje sklonosti Suda spram upuštanja u ispitivanje ispravnosti tumačenja prava od nacionalnih sudova temeljem analiziranih presuda, može se zaključiti da je uspjeh podnositelja pozivanjem na povredu članka 7. zbog načina tumačenja od nacionalnih sudova iznimka. ${ }^{90} \mathrm{U}$ predmetu Custers, Deveaux i Turk protiv Danske ${ }^{91,92}$ Sud navodi da se "neće upuštati u ispitivanje ispravnosti tumačenja prava od strane nacionalnih sudova, osim ako je došlo do flagrantnog nepridržavanja ili samovolje u primjeni navedenih odredaba. “ Štoviše, Sud je zauzeo stav da članak 7. ne štiti adresata od izmijenjene interpretacije

85 Članak 7. Europske konvencije za zaštitu ljudskih prava i temeljnih sloboda, dostupno na: https://www.echr.coe.int/Documents/Convention_ENG.pdf (3. 2. 2020.). Case of Kononov v. Latvia, Application no. 36376/04, Judgment 17 May 2010 Case of Streletz, Kessler and Krenz v. Germany, Applications nos. 34044/96, 35532/97, 44801/98, Judgment 22 March 2001. Case of Korbely v. Hungary, Application no. 9174/02, Judgment 19 September 2008. Vidi KRSTULOVIĆ DRAGIČEVIĆ, A.: Načelo zakonitosti u praksi Europskog suda za ljudska prava Hrvatski ljetopis za kaznene znanosti i praksu, vol. 23, br. 2, Zagreb, 2016. str. 403. - 433., dostupno na: https://hrcak.srce.hr/177438, (30. 1. 2020.). Ibid, str. 410. Case of Custers, Deveaux and Turk v. Denmark, Applications nos. 11843/03, 11847/03 an d 11849/03, Judgment 3 May 2007. 2012. 
koja ide na štetu podnositelja zahtjeva. ${ }^{93}$ Suprotno navedenim stavovima, Sud je utvrdio da je članak 7. odnosno načelo zakonitosti povrijeđeno zbog promjena sudske prakse jer podnositelj zahtjeva nije mogao predvidjeti da će se njegovo ponašanje smatrati deliktom. ${ }^{94}$

Na ovom mjestu navedeni su samo neki predmeti koje je Sud razmatrao u okviru načela zakonitosti i članka 7 . Konvencije. Iz gore spomenutih predmeta može se zaključiti da Sud izbjegava ulaziti u sadržaj tumačenja nacionalnih sudova, priznaje mogućnost promjene tumačenja neke pravne norme (čak i na području kaznenog zakonodavstva gdje je prisutna opća isključujuća norma i vrijedi zabrana analogije!), ali Sud zahtijeva predvidivost pravne norme koja je, u ovom smislu shvaćena, dio šire pravne vrijednosti, pravne sigurnosti.

\section{Zaključak}

Tumačenje je složen postupak koji se sastoji od utvrđivanja mogućih značenja pravne norme koja se treba primijeniti i odluke o tome koje od utvrđenih značenja primijeniti u konkretnom slučaju. Osim pravnih normi, tumače se i činjenice predmetnog slučaja kako bi se podvele pod odgovarajuću pravnu normu. U radu su prikazana različita pravila, argumenti tumačenja, koji bi trebali olakšati zadatak primjenjivaču pravne norme i utvrdili jednu pravilnost i dali nužnu komponentu znanstvene preciznosti postupku tumačenja. Međutim, budući da tumačenje oživotvoruje i dostvarava norme određenog pravnog sustava, nužno je dopustiti određenu fleksibilnost. Fleksibilnost u primjeni pravne norme ne smije voditi arbitrarnosti suca odnosno one ovlaštene osobe koja primjenjuje pravnu normu. Uistinu je teško utvrditi jasnu granicu između fleksibilnosti i arbitrarnosti, osobito kad se utvrdi postojanje pravne praznine koju treba popuniti.

Svaki je pravni sustav ograničen skup normi. Stoga se u njegovoj primjeni nužno pojavljuju određena ponašanja koja predstavljaju pravno prazan prostor, pravno nekvalificirano ili nedostatno kvalificirano ponašanje. Pred tumačem se u slučaju praznine nalazi složen zadatak. U modernim pravnim sustavima vrijedi načelo zabrane uskrate pravosuđenja. Stoga, i u slučaju pravne praznine sudac mora riješiti spor koji mu je podnesen. Autor je u radu zauzeo stav da u takvim slučajevima sudac ili onaj tko primjenjuje normu istu treba dostvoriti pozivom i u granicama općih pravnih načela. Posebnu pozornost sudac treba pridati načelu zakonitosti kako svojim dostvaravanjem pravne norme ne bi izašao iz okvira načela zakonitosti. Ovakav stav može biti u sukobu s načelom diobe vlasti, za-

93 Case of Cantoni v. France, Application no. 17862/91, Judgment 11 November 1996.

94 Case of Pessino v. France, Application no. 40403/02, Judgment 12 February 2007. 
branom retroaktivnosti i pravnom sigurnosti, ali se pokazuje kao nužnost. Ako bi prihvatili kao tautologiju da je pravni sustav savršen, za posljedicu bi imali pretvaranje sudaca u viva vox legis, odnosno one koji su živi glas zakona.

U radu su analizirani stavovi Europskog suda za ljudska prava u pogledu dopuštenosti prilagodbe zakona sudskom interpretacijom u odnosu na načelo zakonitosti. Osobito bi bilo korisno analizirati stavove sudova u Bosni i Hercegovini u pogledu popunjavanja pravnih praznina stvaralačkim tumačenjem i utjecaj takvog tumačenja na pravnu sigurnost i poštivanje načela zakonitosti. Takva analiza svakako zahtijeva opsežan rad i istraživanje, multidisciplinarni pristup, kao i poteškoće pri istraživanju sudske prakse, prvenstveno zbog složene strukture Bosne i Hercegovine koja podrazumijeva postojanje ustavnih sudova na razini entiteta i države, kao i nepostojanje vrhovnog suda na državnoj razini.

\section{THE INTERPRETATION, LEGAL GAPS AND PRINCPLE OF LEGALITY}

In this article, author analyzes relation between interpretation, legal gaps and principle of legality. The interpretation is one stage in application of legal norm. Legal norms are prescribed abstractly for an indefinite number of cases. Therefore, during the process of applying legal norm, as a previous request, there is request for interpretation. The interpreter's task is to determine possible content of legal norm and to apply these meaning which it fits the best in concrete case. The Jurisprudence has developed rules/methods of interpretation to be applied in interpretation process. Interpretation process requires use a several methods of interpretation in order to determine which of possible meaning is the best in concrete case. However, apart from determining possible content of legal norm, in the legal system sometimes appear such cases that means legal gap. In those cases, interpreter should co-create existent legal norm to make it applicable without violation principle of legality. Also, principle of legality has been discussed by European court of human rights. In this paper author suggest that the court use discretionary powers but only if such discretionary decisions do not violate fundamental legal principles of legal system.

Key words: interpretation, methods of interpretation, legal gap, principle of legality, European court of human rights. 